\title{
PECULIARITIES OF DEGRADATION OF METAL OF WELDED JOINTS OF STEAM PIPELINES OF HEAT POWER PLANTS
}

\author{
V.V. DMITRIK and S.N. BARTASH \\ National Technical University «Kharkov Polytechnic Institute» \\ 21 Frunze Str., 61002, Kharkov, Ukraine. E-mail: svarka126@ukr.net
}

\begin{abstract}
The peculiarities of degradation of structure and damageability of metal of welded joints of the steam pipelines of heat power plants of long-term operation period (more than 250,000 h) under the conditions of creep and low-cyclic fatigue are given. It is shown that welded joints of steels $15 \mathrm{Kh} 1 \mathrm{M} 1 \mathrm{~F}$ and $12 \mathrm{Kh} 1 \mathrm{MF}$ are damaged mostly along the areas of fusion, overheating and partial recrystallization of metal in the near-weld zone and also in the places of joining pipe elements of different thicknesses. 13 Ref., 1 Table.
\end{abstract}

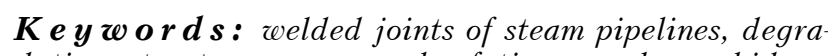
dation, structure, creep cracks, fatigue cracks, carbides

The revealing of peculiarities of degradation of structure of metal of welded joints of steam pipelines of heat power plants of long-term operation period (more than 250,000 h) under the conditions of creep and low-cyclic fatigue is challenging as the effect of initial stage of their damageability. The damageability of steam pipelines mostly occurs simultaneously by the mechanism of creep micropores formation and mechanism of fatigue microcracks formation [1-4]. Welded joints of steam pipelines, characterized by a considerably increased structural, chemical and mechanical heterogeneity, are respectively damaged more intensively (except of bends) than the base metal. The service life of welded joints of steam pipelines amounts approximately to $0.6-0.8$ of the base metal life [2, 5-9, 11-12].

The damageability of welded joints of steam pipelines (Table) is provided by technological, design and service factors. During service life of welded joints of more than 250,000 h, the peculiarities of damageability, revealed by metallographic methods, are strictly different from the similar peculiarities of damageability of welded joints, life duration of which amounts to 60,000200,000 h. [2, 10]. The metal structure of HAZ of welded joints of steam pipelines as well as that of weld and base metal is transformed at different intensiveness into ferrite-carbide mixtures, which are differed by grain size of $\alpha$-phase; level of grains polygonization; rate of carbide reactions $\mathrm{M}_{3} \mathrm{C} \rightarrow \mathrm{M}_{7} \mathrm{C}_{3} \rightarrow \mathrm{M}_{23} \mathrm{C}_{6}$; rate of coagulation of carbides of the group I; level of segregation of chromium and molybdenum in nearboundary zones of grains of $\alpha$-phase; presence of (c) V.V. DMITRIK and S.N. BARTASH, 2014 places, where boundaries of grains of $\alpha$-phase detach from coagulating carbides; local liquidation of grain boundaries of $\alpha$-phase, which can be considered as an initial stage of primary recrystallizaiton [7, 9-10].

The change in metal structure of long-term operated steam pipelines is predetermined by physical and chemical processes, the intensiveness of which in metal of welded joints of steam pipelines is stronger than in their base metal [9$10,13]$. The presence of difference in gradients of chemical potentials of chromium and molybdenum across the section of crystals of $\alpha$-phase causes their diffusion movement to the nearboundary zones of crystals, thus leading to segregation phenomena. The conditions for occurrence of carbide reactions $\mathrm{M}_{3} \mathrm{C} \rightarrow \mathrm{M}_{7} \mathrm{C}_{3} \rightarrow \mathrm{M}_{23} \mathrm{C}_{6}$ are created. The release of carbon from $\mathrm{M}_{3} \mathrm{C}$ and $\mathrm{M}_{7} \mathrm{C}_{3}$ results in formation of new carbides of the group II of $\mathrm{Mo}_{2} \mathrm{C}$ and $\mathrm{VC}$. In carbides the amount of molybdenum reaches to $50 \%$.

It was revealed that VC carbides almost do not coagulate at the service life of welded joints (steels $15 \mathrm{Kh} 1 \mathrm{M} 1 \mathrm{~F}$ and $12 \mathrm{Kh} 1 \mathrm{MF}$ ) up to $300,000 \mathrm{~h}$. It is rational to specify the capability of $\mathrm{Mo}_{2} \mathrm{C}$ carbide to coagulation. The decrease in chromium and molybdenum in the nodes of the crystal of $\alpha$-phase decreases the retardation effect of dislocations, which results in polygonization of grains of $\alpha$-phase (formation of subgrain structure).

At the local clustering of dislocations near the grain boundaries of $\alpha$-phase they can partially penetrate through the boundary and break up in other grain in the form of vacancies, interstitial atoms, and also can cut off the elongated carbides $\mathrm{M}_{23} \mathrm{C}_{6}$. The energy of grains boundaries grows to the level facilitating the formation of dislocations in the neighboring grains. 
VIII INTERNATIONAL CONFERENCE «WELDING CONSUMABLES》

Types of damageability of welded joints of steam pipelines at their long operation (more than 250,000 h)

\begin{tabular}{|c|c|c|}
\hline $\begin{array}{l}\text { Damageability zone. Types of cracks. } \\
\text { Direction of crack propagation }\end{array}$ & Metallographic peculiarities of damageability & Causes of damageability \\
\hline \multicolumn{3}{|c|}{ Creep cracks } \\
\hline $\begin{array}{l}\text { Zones of fusion, overheating and partial re- } \\
\text { crystallization of HAZ metal, weld metal } \\
\text { (WM) and rarely base metal (BM). } \\
\text { The cracks are propagating from the outer } \\
\text { surface of welded joints perpendicularly } \\
\text { to the axis of steam pipeline element. } \\
\text { Transverse cracks are formed in welded } \\
\text { T-joints with a thinned wall of connecting } \\
\text { pipe. }\end{array}$ & $\begin{array}{l}\text { Along the boundaries of the contact of } 3 \\
\text { or } 2 \text { coarse grains of } \alpha \text {-phase, at the places } \\
\text { of contact of grains with coagulating } \\
\text { carbides } \mathrm{M}_{23} \mathrm{C}_{6} \text {. } \\
\text { Along the grain boundaries of } \alpha \text {-phase, } \\
\text { where new products of austenite decay in } \\
\text { the form of granular pearlite (area of } \\
\text { partial HAZ recrystallization) are located. }\end{array}$ & $\begin{array}{l}\text { 1. Design, caused by high concentration } \\
\text { of local stresses, in the zones of contact of } \\
\text { steam pipeline elements of different } \\
\text { thicknesses. Presence of undercuts. } \\
\text { 2. Technological, caused by presence of } \\
\text { original rejected structure or structure } \\
\text { close to the rejected one, which is } \\
\text { predetermined by an increased welding } \\
\text { heat and heat treatment performed with } \\
\text { violation of requirements of standard } \\
\text { documentation; discrepancy of chemical } \\
\text { composition as to requirements of } \\
\text { standard documentation. } \\
\text { 3. Service, caused by service conditions: } \\
\text { difference of real condition of steam } \\
\text { pipelines from the design one; increase in } \\
\text { number of starts-stops of power units; } \\
\text { increased rate of heating up during the } \\
\text { process starting; conditions of } \\
\text { manoeuvrable operation mode of power } \\
\text { units. }\end{array}$ \\
\hline \multicolumn{3}{|c|}{ Corrosion-fatigue cracks } \\
\hline $\begin{array}{l}\text { Zones of contact of pipe elements of differ- } \\
\text { ent thicknesses, areas of fusion, overheat- } \\
\text { ing and partial recrystallization of HAZ } \\
\text { metal, WM and BM (rarely). } \\
\text { The cracks are developing from the inner } \\
\text { surface of welded joints. } \\
\text { Shape of cracks - thread-like, with } \\
\text { branches, in the form of blunt crack filled } \\
\text { with corrosion products, and sharp cracks } \\
\text { with side branches. }\end{array}$ & $\begin{array}{l}\text { Cracks formation occurs along the } \\
\text { boundaries and in body of grains, with } \\
\text { domination of one or another type, which } \\
\text { depends on service conditions. }\end{array}$ & $\begin{array}{l}\text { Initiation and growth of cracks cause } \\
\text { mutual effect of cyclic thermal stresses } \\
\text { and corrosion environment on metal and } \\
\text { are also activated by degradation of } \\
\text { structure. }\end{array}$ \\
\hline
\end{tabular}

The presence of structural, chemical and mechanical heterogeneities results in higher level of degradation of metal of welded joints than of base metal. To improve the reliability of operation of welded joints of steam pipelines and to increase their service life it is rational to delay the physical and chemical processes, which occur in their metal at the long operation under the conditions of creep and low-cyclic fatigue, that can be possible by applying steels of new generation.

1. Antikajn, P.A. (2001) Metals and strength design of boilers and pipelines. Moscow: Energoservis.

2. Khromchenko, F.A. (1992) Service life of welded joints of steam pipelines. Moscow: Mashinostroenie.

3. Dmitrik, V.V. (2013) Welded joints of steam pipelines. Kharkov: Majdan.

4. Dmitrik, V.V., Tsaryuk, A.K., Bugaets, A.A. et al (2006) Evaluation of remaining life of welded joints of pipelines for thermal power plants. The Paton Welding J., 2, 6-10.

5. Dmitrik, V.V. (2004) To creep of welded joints from low-alloy $\mathrm{Cr}-\mathrm{Mo}-\mathrm{V}$ heat-resistant pearlitic steels Vost.-Evrop. Zhurnal Pered. Tekhnologij, 6, 88-92.

6. $R D$ 135-34. 1-003-01 (RTM-1s): Welding, heat treatment and control of pipe systems of boilers and pipelines in mounting and repair of power equipment.
7. Anokhov, A.E., Alekseeva, I.A. (1982) Accumulation of damages in welded joints of steam pipelines from $12 \mathrm{Kh} 1 \mathrm{MF}$ steel during creep process. Svarochn. Proizvodstvo, 9, 34-35.

8. Khromchenko, F.A. (2001) Reliability of welded joints of pipes, boilers and steam pipelines. Moscow: Energoizdat.

9. Berezina, T.G., Borodina, E.R., Ashikhmina, L.A. et al. (1974) Fine structure of heat affected zone in welding of $15 \mathrm{Kh} 1 \mathrm{M} 1 \mathrm{~F}$ steel. Avtomatich. Svarka, 12, 19-22.

10. Khromchenko, F.A., Kalugin, R.I., Lappa, V.A. et al. (1999) Peculiarities of structural changes in welded joints of $15 \mathrm{Kh} 1 \mathrm{M} 1 \mathrm{~F}$ steel during creep. Svarochn. Proizvodstvo, 10, 12-15.

11. MU34-70-161-87: Technical recommendations on metallographic analysis in evaluation of quality and investigation of damage causes of steam pipeline welded joints of $12 \mathrm{Kh} 1 \mathrm{MF}$ and $15 \mathrm{Kh} 1 \mathrm{M} 1 \mathrm{~F}$ steels for heat power plants. Moscow: F.E. Dzerzhinsky VTI.

12. $R D$ 34.17.421-92: Type instruction on control and service life prolongation of metal of boiler base elements, turbines and pipelines of heat power plants. Moscow: ORGRES Service of best practice.

13. Dmitrik, V.V., Shelepov, I.G. (2005) To evaluation of remaining life of welded joints of heat power plant pipelines on structural factors. Energetika $i$ Elektrifikatsiya, 9, 41-43. 